\title{
Risk Management in Crop Production Based on the Regional Index
}

\author{
Željko Kokot* · Todor Marković · Nemanja Pajić \\ University of Novi Sad, Faculty of Agriculture, Trg Dositeja Obradovića 8, 21000 Novi Sad, Serbia
}

\begin{abstract}
Summary: Regional index insurance is one of the newer instruments for reducing losses in crop production. The regional index indicates the average yield or average production value in a region, representing the basis for the premium calculation and insurance benefits. The main advantage of this insurance model is that it does not require the damage assessment, which is one of major problems in the relationship between the insured and insurer. In the case of corn, wheat and sunflower production as the most important crops in the region of Ada municipality, the authors describe the methodology of application of the analysed insurance system. Implementation of this contemporary form of insurance in Serbia would reduce the negative financial consequences in agricultural production. The abovementioned model of insurance can be seen as a significant alternative to conventional insurance, which can increase insured area and number of insured, and trust and confidence in insurance companies would also be restored. Key words: crop production, crops, insurance, regional index, risk management
\end{abstract}

\section{Introduction}

In recent years, we have witnessed accelerated climate changes around the world. Unpredictable climatic events and natural disasters largely affect lives of all people on our planet, as well as the various economic activities. Based on the research it is estimated that $80 \%$ of the world economy depends on the fluctuations of weather factor (Auer, 2003). Climate changes particularly affect the results achieved in agriculture. The risk of occurrence of harmful events increases because it is a sector of the economy directly affected by weather conditions. For these reasons, the issue of reducing weather risks has become increasingly popular in contemporary agricultural economics literature (Du et al., 2015; Goodwin \& Hungerford, 2015; Enjolras et al., 2014).

Undoubtedly, the best possible way to manage weather risks in the agricultural production is crop insurance. During the previous period, some of the traditional insurance model showed many disadvantages. Risk management in the agricultural production, especially crop production has not been

Corresponding author:

zeljko.kokot5@gmail.com

Acknowledgement:

This study is part of the project III46006 "Sustainable agriculture and rural development in order to achieve strategic goals of the Republic of Serbia in the Danube region", financed by the Ministry for Education, Science and Technological Development of the Republic of Serbia. fully resolved, and there is always a constant need to develop new models of insurance. Constant development of crop insurance has contributed to the creation of a large number of the insurance system. Depending on the criteria, systems of crop insurance can be divided in different ways, and one of the most comprehensive classification differs yield insurance, revenue and income insurance, whole-farm insurance and index insurance (Markovic \& Jovanovic, 2011).

From all mentioned insurance systems, index insurance belongs to a group of the latest models of insurance, and its greater implementation is certainly expected in the near future. This group of insurance includes insurance based on the regional index and weather derivatives. Insurance based on the regional index presents alternative to traditional yield insurance from a number of risks, and this form of insurance takes an average yield or the average realized value of production in the specific region as a parameter (Markovic, 2013).

In this paper, special attention will be paid to the insurance based on the regional index. In this model, insurance premium is realized if the regional average yield is below the expected long-term average yield (Skees et al., 1997), whereby it should be proved whether the total payment under the insurance is conditioned by changes of yield. This type of insurance was created in the mid of the last century as an alternative to individual yield insurance, with the aim of reducing moral-hazard and adverse selection (Halcrow, 1949), but a lot more attention was paid in the 90s when 
this model of insurance came again into the focus of scientific interest (Miranda, 1991). The condition for the implementation of this concept is the creation of geographic regions that are homogeneous with regards to climatic conditions. This assumes that all farmers from the region pay the same insurance premium and during the occurrence of the insured event are also compensated in equal amounts (Ebneth, 2003).

A significant advantage of this model is reflected in the reduction of moral hazard compared to the traditional insurance, since individual insured have no influence on the amount of realized regional index, as well as on the level of compensation (Chambers \& Quiggin, 2002). Also, the insurance based on the amount of regional index, is less susceptible to asymmetric information, and does not require the determination of expected yields and/or revenue for each individual farm (Deng et al., 2008).

In addition, the mentioned model enables farmers to better ensure comprehensive protection against all risks in relation to the certain individual insurances (Schlieper, 1997). Among the other advantages of insurance based on regional index, elimination of adverse selection, reducing transaction costs, lower franchise and a higher level of coverage should be single out (Wolf, 1998; Ebneth, 2003; Hirschauer \& Mußhoff, 2008).

Furthermore, it is assumed that the amount of insurance premium per unit of capacity is lower than the amount of premiums in the classical and indirect index insurance, which will be proven hereunder. Several models for determining the amount of the insurance premium can be applied with this insurance system. According to the model used by the World Bank, in a study dedicated to the crop insurance in Senegal, the premium is calculated as the sum of the expected loss, margin risk and administrative costs. Also, the premium can be counted as the sum of the actuarial fair premiums, which is adjusted to risk, and certain administrative and operating costs (Smith \& Watts, 2009).

In Serbia, most of the insurance companies still mainly apply traditional systems of insurance from yield reduction, which are based on damage assessment, whereby farmers are insuring themselves from basic risks (hail, fire and lighting) and some other additional risks. There are no modern systems of crop insurance, although some empirical data indicate a real need for the mentioned models. Insurance based on regional index is certainly one of those whose implementation in Serbia would be desirable. For these reasons, the research aim in this paper is elaboration of theoretical foundation and display of the practical examples of the functioning of the analysed insurance model, the characteristics of which are insufficiently known to domestic agricultural economics public.

\section{Materials and Methods}

Data from Statistical Office of the Republic of Serbia (SORS) of the average area and yield of corn, wheat and sunflower in the Ada municipality are used for this study. Data were analysed during the period of five years (2009-2013). The application of insurance based on regional index is shown in the case of the mentioned municipality. When using this model, the average yield in the analysed period is used as regional index, and insured area refers to the average area under individual crops in the observed region. Simulation of application of the analysed insurance system at guaranteed yields of $80 \%$ of expected municipal yield is done, with assumption that yields lower and higher than average are achieved. Insured value of certain crops per yield unit is taken from the Commodity Exchange in Novi Sad. The sum insured per area unit is calculated as the product of the two values or guaranteed (insured) yield and the contracted value per yield unit and the total sum insured was obtained as a product of the sum insured per area unit and total insured surface. The insurance premium is calculated as the product of the premium rate $(4.6 \%)$ and the insured sum per unit area (Carter et al., 2007). Finally, simulation leads to the possible amount of loss, which can be compensated by using the analysed model, as well as to the payment amount. Actual loss $(\mathrm{L})$ is the quotient of the difference of the insured $\left(I_{y}\right)$ and achieved yield $\left(A_{y}\right)$ and the insured yield $\left(\mathrm{I}_{\mathrm{y}}\right)$ :

$$
\mathrm{L}=\frac{\mathrm{Iy}-\mathrm{Ay}}{\mathrm{Iy}} \times 100 \%
$$

On the other hand, the payment of insurance $(\mathrm{P})$ is obtained as the product of the actual loss (L) and the total insured sum $\left(\mathrm{T}_{\mathrm{si}}\right)$ :

$$
\mathrm{P}=\mathrm{L} \times \mathrm{T} \text { si }
$$

Based on the foregoing calculation, total value of loss in the surveyed productions (corn, wheat, sunflower) is obtained, which can be recovered by using the analysed insurance model.

\section{Results and Discussion}

On the territory of the surveyed municipality of Ada, the most commonly grown crops are corn, wheat and sunflower. They are grown on more than 15,000 ha. The dominant position is occupied by corn, with over $60 \%$ of the cultivated area. The three most common crops are characterized by large fluctuations in the realized total production in certain years, with the resulting coefficients of variation in corn $29.26 \%$, wheat $47.09 \%$, and $17.14 \%$ in sunflower.

The cause of the obtained parameters is certainly the occurrence of different production risks faced by each of the three analysed production. The consequences are lower production, lower overall income on level of all 
agricultural producers in the observed municipality, and therefore the achievement of the weaker financial results per capacity unit. Because the risks in the agricultural sector are specific, their management requires specific models, too.

The model of insurance which includes insurance of yield loss in certain crops in the region was analysed in this paper. In the specific case of the production of corn, wheat and sunflower, an example of index insurance at the municipal level is given, within which protection against the production losses is provided through the insurance and reinsurance of the consequences of natural and climate risks (drought, floods, storms, excessive rainfall et al.), which can lead to a significant reduction in yield and income. There are several key differences between insurance, which are concluded from micro point of view, or at the level of individual farmer and insurances that are concluded at the so-called meso-level, respectively from the aspect of local government/municipality.

Table 1. Production of corn, wheat and sunflower in Ada municipality (2009-2013)

\begin{tabular}{|c|c|c|c|c|c|c|}
\hline & \multirow{2}{*}{ Parameter } & \multirow{2}{*}{$\begin{array}{l}\text { Average } \\
\text { (without } \\
\text { extreme) }\end{array}$} & \multirow{2}{*}{$\begin{array}{l}\text { Coefficient of } \\
\text { variation }(\%)\end{array}$} & \multicolumn{2}{|c|}{ Interval of variation } & \multirow{2}{*}{$\begin{array}{c}\text { Change rate } \\
(\%)\end{array}$} \\
\hline & & & & Min & $\operatorname{Max}$ & \\
\hline \multirow{3}{*}{$\begin{array}{l}\mathrm{C} \\
\mathrm{O} \\
\mathrm{r} \\
\mathrm{n}\end{array}$} & $\begin{array}{l}\text { Area } \\
\text { (ha) }\end{array}$ & 11,773 & 5.06 & 10,841 & 12,436 & -2.12 \\
\hline & $\begin{array}{c}\text { Yield } \\
\left(\mathrm{kg} \mathrm{ha}^{-1}\right)\end{array}$ & 5,508 & 30.45 & 2,654 & 6,996 & 2.05 \\
\hline & Production $(\mathrm{t})$ & 64,846 & 29.26 & 33,005 & 81,727 & -0.12 \\
\hline \multirow{3}{*}{$\begin{array}{l}\text { W } \\
\mathrm{h} \\
\mathrm{e} \\
\mathrm{a} \\
\mathrm{t}\end{array}$} & $\begin{array}{l}\text { Area } \\
\text { (ha) }\end{array}$ & 2,508 & 22.65 & 1,898 & 3,347 & 6.17 \\
\hline & $\begin{array}{c}\text { Yield } \\
\left(\mathrm{kg} \mathrm{ha}^{-1}\right)\end{array}$ & 4,094 & 25.47 & 3,219 & 5,682 & 11.32 \\
\hline & Production (t) & 10,268 & 47.09 & 6,110 & 19,018 & 18.19 \\
\hline $\begin{array}{l}\mathrm{S} \\
\mathrm{u} \\
\mathrm{n}\end{array}$ & $\begin{array}{c}\text { Area } \\
\text { (ha) }\end{array}$ & 1,095 & 13.28 & 940 & 1,267 & 3.59 \\
\hline $\begin{array}{l}f \\
1 \\
o\end{array}$ & $\begin{array}{c}\text { Yield } \\
\left(\mathrm{kg} \mathrm{ha}^{-1}\right)\end{array}$ & 2,315 & 7.25 & 2,147 & 2,608 & 4.98 \\
\hline $\begin{array}{l}\mathrm{w} \\
\mathrm{e} \\
\mathrm{r}\end{array}$ & Production $(\mathrm{t})$ & 2,535 & 17.14 & 2,216 & 3,192 & 8.75 \\
\hline
\end{tabular}

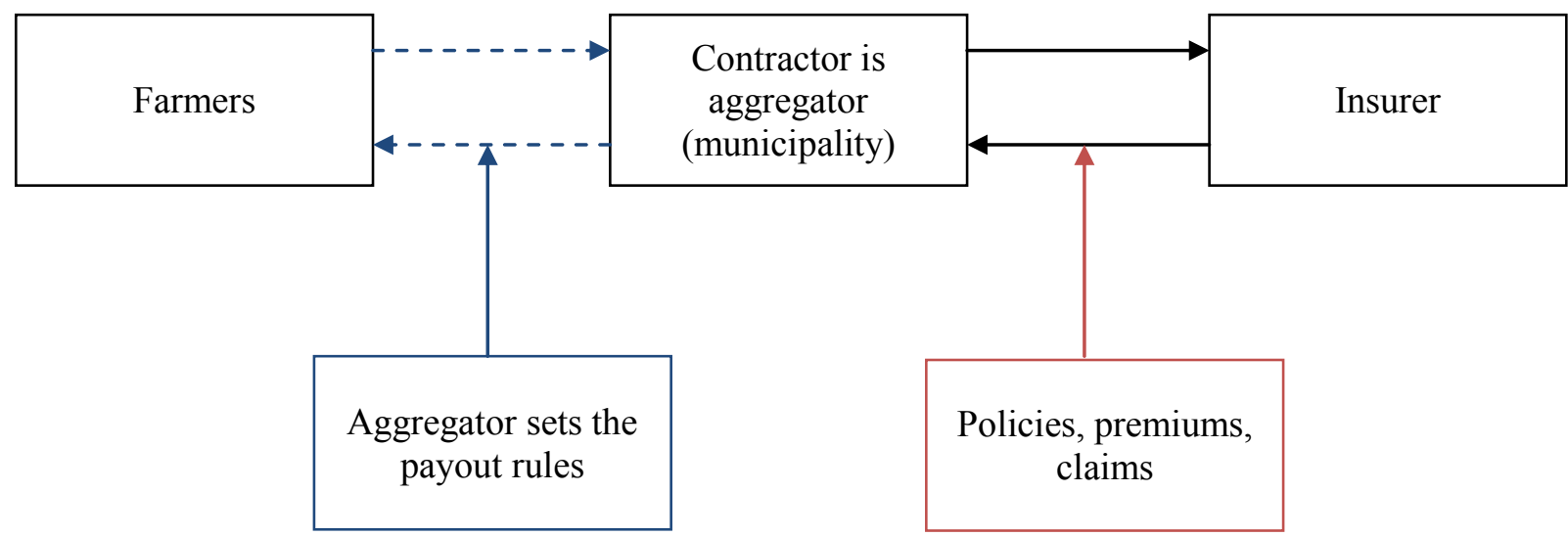

Figure 1. Meso-level of program for yield protection crop insurance in Serbia Source: www.europa-re.com 
The differences lie in the fact that at the meso-level local government, namely municipality, appears in the function of policy holder and insured, whereby it is responsible for paying the entire insurance premium. The municipality needs to decide which farmers should be ensured, what crops will be covered by insurance, then it should decide on the width of the yield protection program that wants to buy i.e. total area that wishes to insure, also the level of insurance coverage, yield, as well as the sum insured per area unit. The role of insurance companies in this model is premium collection and compensation payment, as well as in the case of traditional insurance models. The main difference is reflected in the existence of aggregators (municipalities). In the event that the actual yield on a municipal level is below the agreed yield, the right to compensation is acquired. Compensation is calculated based on the percentage reduction of the agreed yields. Area yield based insurance allows to conclude guaranteed (insured) yield and yield coverage of at least $60 \%$ but less than $90 \%$ of municipal expected yield. Below, there is an example of the functioning of this new mechanism of insurance, i.e. example of calculation of insurance indemnity in the case of contracted insurance of a decrease in yield of corn, wheat and sunflower, at option of reduction of $20 \%$ of the average municipal yield.

In the five-year period at the level of analysed municipality of Ada, without extreme values, in corn production an average yield of $5,508 \mathrm{~kg} \mathrm{ha}^{-1}$ is achieved, in wheat production 4,094 $\mathrm{kg} \mathrm{ha}^{-1}$, while in sunflower production an average yield of 2,315 kg ha-1. Mentioned crops were cultivated on 11,773 ha (corn), 2,508 ha (wheat) and 1,095 ha (sunflower). Based on average data of areas and actual yields, values of guaranteed yield and insurance amount per area unit are obtained, as well as ultimately the total sum insured. In 2016 certain yields are assumed which are lower and higher than the average for all three analysed crops. The option with a lower yield, using the formula (1) specified in the methods of paper, is assuming realized losses of $19.66 \%$ in the corn production, $16.95 \%$ in the wheat production and $15.28 \%$ in sunflower production. Based on this, the insurance payment shall be made on the basis of formula (2) and payments amount to 163 million RSD with the insured corn production (13,860 RSD ha-1), 25 million RSD for wheat (9,992 RSD ha-1), and 11 million RSD for sunflower $\left(10,187 \mathrm{RSD} \mathrm{ha}^{-1}\right)$. Thus, in a hypothetical option with a lower yield than the average, the insurer would be obliged to cover the total cost of 199 million RSD for all three analysed crops, while in option with a higher yield, the payout does not exist. Irrespective of the achieved yield, insured persons have an obligation to the insurer in the amount of 48 million RSD, which is the total insurance premium at the level of observed municipality for all three major crops. The amounts of insurance premium per unit of capacity (corn 3,243 RSD ha-1, wheat 2,712 RSD ha-1, sunflower 3,067 RSD ha-1) were about the same, or even at the lower level, compared with conventional insurance premiums (Marković, 2013), or below the level of the premium for indirect index insurance (Marković et al., 2013).

Total payments from insurance are directly caused by changes in yield. With the increase of yield, total payments from insurance reduce and at a given point are equal to zero, i.e. insurance payments will not be achieved if the average yield at the level of the analysed region (municipality) reaches a height of guaranteed yield. In cases with an $80 \%$ coverage level, guaranteed yield of corn amounts to $4,406 \mathrm{~kg} \mathrm{ha}^{-1}$, wheat amounts to $3,275 \mathrm{~kg} \mathrm{ha}^{-1}$ and sunflower $1,852 \mathrm{~kg} \mathrm{ha-1}$. In the next section, the presentation of contingent insurance payment follows, depending on the movement of achieved yield.

Similar observations apply to other coverage levels. The main differences are reflected in the amount of the guaranteed yield, the amount of the total insured sum and the amount of insurance payment. The aforementioned parameters have less value if coverage level is lower. Irrespective of the defined coverage level, this model insures all yields lower than the insured (guaranteed) yield.

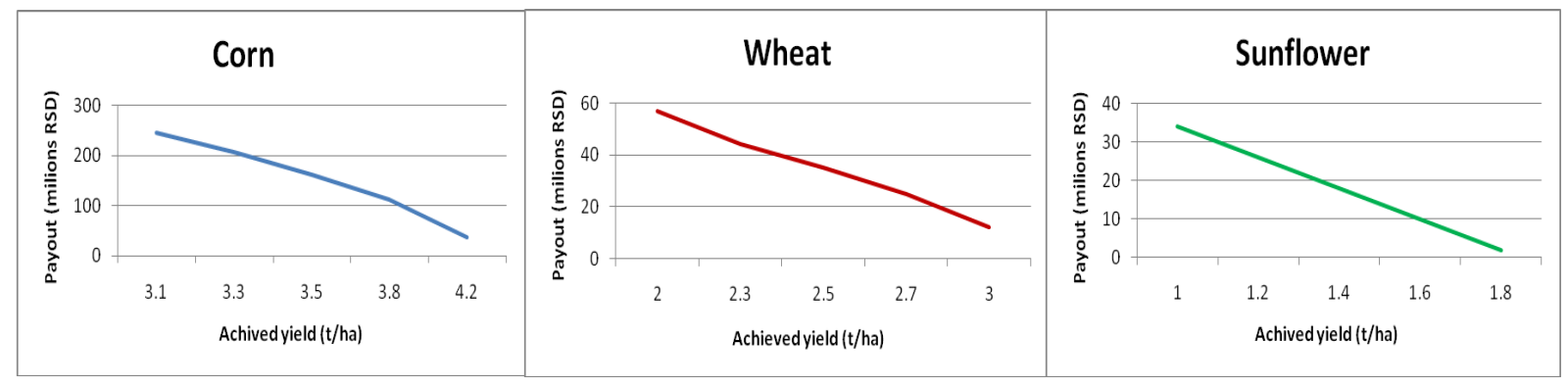

Figure 2. Movement of insurance payment at the level of observed municipality 
Table 2. The calculation of insurance benefit by using model based on regional index

\begin{tabular}{|c|c|c|c|c|c|c|}
\hline \multirow[b]{2}{*}{$\begin{array}{l}\text { Contracted level of insured } \\
\text { coverage (insured yield in \%) }\end{array}$} & \multicolumn{2}{|c|}{ Corn } & \multicolumn{2}{|c|}{ Wheat } & \multicolumn{2}{|c|}{ Sunflower } \\
\hline & 80 & 80 & 80 & 80 & 80 & 80 \\
\hline $\begin{array}{l}\text { Guaranteed (insured) yield } \\
\left(\mathrm{kg} \mathrm{ha}^{-1}\right)\end{array}$ & 4,406 & 4,406 & 3,275 & 3,275 & 1,852 & 1,852 \\
\hline Contracted price (RSD kg-1) & 16 & 16 & 18 & 18 & 36 & 36 \\
\hline Sum insured per ha (RSD ha-1) & 70,496 & 70,496 & 58,950 & 58,950 & 66,672 & 66,672 \\
\hline Insured area (ha) & 11,773 & 11,773 & 2,508 & 2,508 & 1,095 & 1,095 \\
\hline Total sum insured (RSD) & $829,949,408$ & $829,949,408$ & $147,846,600$ & $147,846,600$ & $73,005,840$ & $73,005,840$ \\
\hline Achieved yield in $2016(\mathrm{~kg})$ & 3,540 & 7,476 & 2,720 & 5,468 & 1,569 & 3,061 \\
\hline Actual loss & 0.19655 & 0 & 0.16947 & 0 & 0.15281 & 0 \\
\hline Actual loss in $\%$ & 19.66 & 0 & 16.95 & 0 & 15.28 & 0 \\
\hline Insurance payout $\left(\mathrm{RSD} \mathrm{ha}^{-1}\right)$ & 13,860 & 0 & 9,992 & 0 & 10,187 & 0 \\
\hline Insurance payout (RSD) & $163,168,054$ & 0 & $25,059,999$ & 0 & $11,155,292$ & 0 \\
\hline $\begin{array}{l}\text { Insurance premium amount } \\
\left(\mathrm{RSD} \mathrm{ha}^{-1}\right)\end{array}$ & 3,243 & 3,243 & 2,712 & 2,712 & 3,067 & 3,067 \\
\hline $\begin{array}{l}\text { Insurance premium amount } \\
\text { (RSD) }\end{array}$ & $38,179,839$ & $38,179,839$ & $6,801,696$ & $6,801,696$ & $3,358,365$ & $3,358,365$ \\
\hline
\end{tabular}

$1 €=120 \mathrm{RSD}$ (Serbian dinar)

\section{Conclusions}

As one of the most important sectors of the economy, agricultural production faces many production risks, and as such those risks must be well managed. It is reflected in direct dependence on the achieved results and present weather (none) conditions. To manage these specific risks, the best solution is offered by various insurance systems. One of the newer models is area yield based insurance which use can greatly reduce the significant damages that frequently affect particular regions. In the case of the analysed municipality of Ada, observing the three most common crops, the potential production losses (corn 19.66\%, wheat $16.95 \%$, sunflower $15.28 \%$ ) can be compensated as a maximum payout of 199 million RSD at the level of $80 \%$ coverage, whereby total payments from insurance are directly caused by changes in yield. On the other hand, the cost of insurance premiums for individual crops (corn 3,243 RSD ha-1, wheat 2,712 RSD ha-1 and sunflower 3,067 RSD ha-1) may be lower than in the traditional crop insurance and indirect index insurance, which is certainly positive in terms of the limited financial power of farmers. With clear strategy on the state level, establishing a legal framework and financial incentives, analysed insurance model could be successfully implemented in Serbia, and therefore many farmers who perform their activity in climatic unstable regions, will be insured.

\section{References}

Auer, J. (2003). Weather Derivatives Heading for Sunny Times. Deutsche Bank Research, 25 February, Frankfurt Voice.

Carter, M. R., Galarza, F., \& Boucher, S. (2007). Underwriting Areabased Yield Insurance to Eliminate 'Risk Rationing' and Crowd in Credit Supply and Demand. International Conference on Rural Finance Research: Moving Results into Polices and Practice, 16-17, Rome.

Chambers, R. G., \& Quiggin, J. (2002). Optimal Producer Behavior in the Presence of Area-Yield Crop Insurance. American Journal of Agricultural Economics, 84(2), 320-334. 
Deng, X., Barnett, B. J., Hoogenboom, G., Yu, Y., \& Garcia, A. (2008). Alternative Crop Insurance Indexes. Journal of Agricultural and Applied Economics, 40(1), 223-237.

Du, X., Ifft, J., Lu, L., \& Zilberman, D. (2015). Marketing Contracts and Crop Insurance. American Journal of Agricultural Economics, 97 (5), 1360-1370.

Ebneth, O. J. (2003). Mehrgefahrenversicherung als Risiko-ManagementInstrument für die Deutsche Landwirtschaft. Master Thesis. Göttingen: Fakultät für Agrarwissenschaften.

Enjolras, G., Capitanio, F., Aubert, M., \& Adinolfi, F. (2014). Direct payments, crop insurance and the volatility of farm income. Some evidence in France and in Italy. New medit: Mediterranean journal of economics, agriculture and environment, 13(1), 31-40.

Goodwin, B. K., \& Hungerford, A. (2015). Copula-based models of systemic risk in US agriculture: implications for crop insurance and reinsurance contracts. American Journal of Agricultural Economics, 97(3), 879-896.

Halcrow, H. G. (1949). Actuarial Structures for Crop Insurance. Journal of Farm Economics, 31(3), 418-443.

Hirschauer, N., \& Mußhoff, O. (2008). Risikomanagementinstrumente im Vergleich: Sollte man landwirtschaftliche Ernteversicherungen subventionieren? - Gute alte Argumente in einem neuen Streit, Vortrag anlässlich der 48. Jabrestagung der GEWISOLA ,Risiken in der Agrar und Ernährungswirtschaft und Ibre Bewältigung ", 24.-26. September, Bonn
Marković, T., \& Jovanović M. (2011). Uticaj količine padavina na prinos pšenice i kukuruza kao proizvodni bazni rizik, Ratarstvo $i$ Povrtarstvo, 48(1), 207-212.

Marković, T., Ivanović, S., \& Todorović, S. (2013). Reduction in Revenue Volatility in Maize Production Applying the IndirectIndex Insurance. Economics of Agriculture, 60(3), 445-454.

Marković, T. (2013). V remenski derivati i upravljanje rizikom u polioprivredi. Novi Sad: University of Novi Sad, Faculty of Agriculture.

Miranda, M. J. (1991). Area-Yield Crop Insurance Reconsidered. American Journal of Agricultural Economics, 73, 233-242.

Schlieper, P. (1997). Ertragsausfallversicherung und Intensität pflanqlicher Produktion. Wiesbaden: Deutscher Universitätsverlag

Skees, J. R., Black, J. R., \& Barnett, B. J. (1997). Designing and Rating an Area Yield Crop Insurance Contract, American Journal of Agricultural Economics, 79, 430-438.

Smith, H. V., \& Watts M. (2009). Index Based Agricultural Insurance in Developing Countries: Feasibility, Scalability and Sustainability. Retrieved from: http://citeseerx.ist.psu.edu/viewdoc/ download?doi=10.1.1.476.4002\&rep $=$ rep1\&type $=$ pdf.

World Bank (2009). Index-based Crop Insurance in Senegal, Promoting Access to Agricultural Insurance for Small Farmers. The World Bank.

Wolf, T. (1998). Ernteversicherungssysteme als Risk-Management Instrument für den Landwirt und ihr Einsatz im Rahmen der US-Agrarpolitik. Masterarbeit, München-Weihenstephan

\section{Upravljanje rizikom u biljnoj proizvodnji zasnovano na regionalnom indeksu}

\section{Željko Kokot · Todor Marković · Nemanja Pajić}

Sažetak: Osiguranje zasnovano na regionalnom indeksu predstavlja jedan od novijih instrumenata za smanjenje gubitaka u biljnoj proizvodnji. Regionalni indeks označava prosečan prinos ili prosečnu vrednost proizvodnje u nekom regionu koji predstavlja osnovu za izračunavanje premije i naknade iz osiguranja. Osnovna prednost ovog modela osiguranja je u tome što ne zahteva procenu štete, a to predstavlja jedan od značajnih problema na relaciji osiguranik-osiguravač. Na primeru proizvodnje kukuruza, pšenice i suncokreta, kao najvažnijih useva u regionu opštine Ada, autori prikazuju metodologiju primene analiziranog sistema osiguranja. Implementacijom ovog savremenog oblika osiguranja u Srbiji umanjile bi se negativne finansijske posledice u poljoprivrednoj proizvodnji i zaštitili poljoprivredni proizvođači od različitih proizvodnih rizika. Navedeni model osiguranja može predstavljati značajnu alternativu klasičnom osiguranju, koji bi povećao osigurane površine i broj osiguranika, a povratilo bi se $\mathrm{i}$ poverenje u osiguravajuće kompanije.

Ključne reči: biljna proizvodnja, osiguranje, regionalni indeks, usevi, upravljanje rizikom 